\title{
鋼床版 2 主桁橋の横断面変形特性について \\ CROSS-SECTIONAL DEFORMATION OF TWO SINGLE-WEB \\ MAIN GIRDER BRIDGES WITH STEEL PLATE DECK
}

\author{
加 藤 隆 夫* • 丸 山 忠 明** \\ By Takao KATO and Tadaaki MARUYAMA
}

\section{1. まえがき}

2 主桁橋はいうまでもなく 2 本の主桁からなる桁橋で あり，小幅員・小支間の橋に対しては古くから用いられ てきた形式であるが，ここで述べる 2 主桁橋は，経済的 な設計の追求から生まれた幅員の広い, 支間長の大きい 構造を有するものを対象とする.

このような 2 主桁橋においては，2本の主桁は相当広 い間隔で配置される.その場合，横構については省略さ れることが多く,さらに，床組，および対傾構部材につ いても, 軽量化を図る観点から, 構造法に種々の工夫が 加えられている.

このような橋梁形式が登場したのは, 1950 年代の中 頃からであり, 鋼床版 2 主桁橋では St. Alban 橋 ${ }^{2}$, 合 成 2 主桁橋では Sulzbachtal 橋 ${ }^{3}$ が最初のものと考えら れる. 以来 20 余年が経過し, 相当数の橋がこの形式に よって実施されている11.

さて，2主析橋注全体として， $\pi$ 形状に形成される大 形の薄肉構造物であるが, 実際上, その設計には従来, ふたつの方法が適用されてきた．そのひとつは, 床版の 有効幅部分を上フランジとする 2 本の主桁に分離し, 10 の反力影響線を用いて荷重の分配を行い, 個々独立に 設計するものであり，慣用設計法としてよく用いられて いる方法である（以下，慣用法という).いまひとつは， 構造とその特性をできるだけ忠実に $\pi$ 形桁として取り扱 おうとするものである。

過去の実施例として, Inn 橋 ${ }^{4}$ や新十三大橋(5) におい ては, 曲げねじり理論6) の適用により, 慣用法の照查が 行われている. また, Golden Horn 橋?) では, 床組構 造と横断面補剛部材の設計を主目的に，構造全体を骨組 に置換した解析が実施されている. しかし, 前者の事例

* 正会員 工博 大阪市土木局街路部計画課長

** 正会員 工修 大阪市土木局土木部橋梁課第 1 設計倸
では，横断面の変形は無視され，また，デッキプレート におけるせん断遅れの影響については，有効幅を考える ことにより配慮するものとしている，一方，後者の方法 は，主析の設計に適用する場合，デッキプレートや主桁 腹板等の板部材が骨組化されている点で仮定が大きすぎ るように思われる。

ところで, 横断面変形を考慮した主桁の設計問題は, 従来, 箱析橋に多くの関心が寄せられている.これに関 して, V.Z. Vlasov ${ }^{8)}$ の一般化座標法を応用した広範な 研究が G. Lacher ${ }^{9)}$, 奥村・坂井 ${ }^{10), 11)}$, 落合・北原 ${ }^{12)}$, 坂井・長井 ${ }^{13)}$ らによって行われている. その場合, 主と して, 箱桁の隔壁ないしは対傾構のせん断変形が注目さ れている. 2 主桁橋については，今日までこの種の研究 は報告されていないが, 対傾構めるいはこの機能を兼ね た床組を軽量化する場合, 横断面補剛構造部材はかなり の柔構造となり, この問題に対する検討は不可避の課題 と考えられる.

著者らは, 模型桁による載荷実験から, 横断面部材の 曲げ変形に伴う, 主桁下フランジの水平変位および, 水 平付加曲げモーメントが, 設計上無視し得ない值に達す ることを知り, この点に関して, 構造解析による解明と 実際設計に必要な資料の整理を試みている ${ }^{14)}$.

本文では，まず 2 主桁橋の実施例を参照し，横断面の 補剛形式について分類・整理する.さらに鋼床版 2 主桁 橋に関して, 横断面変形の影響を明らかにするために, ふたつの解析法による計算值と実橋載荷実験の測定值を 対比し, 考察を加える.

また最も軽量化された，ふたつの横断面補剛形式に注 目し，支間・主桁間隔・補剛部材の諸元等が種々に変化 する場合についてパラメーター解析を実施し，特に影響 の大きな主桁下フランジの水平変位と水平付加曲げモー メントに関して, 資料を提供する.さらに, 主桁下フラ ンジに対する横断面変形の影響を求めるた为の近似解法 についても, 検討を加える. 


\section{2 主椼橋における横断面の補剛形式と変形}

前述のように 2 主桁形式のねらいとするところは, 床 組ないしは横断面補剛部材の節減により, 経済的な設計 を達成する点にあるといえる.この観点に基づき，今日 まで横断面の補剛機能を含めた床組の構造法について, 種々の工夫が重ねられてきた. この結果, 実施例につい て考察する場合には, 床組と横断面の補剛を目的とした いわゆる対傾構に関する構造的な区分は必ずしも明確で なく, むしろ両者の機能を兼ねた構造が多く見受けられ る.ここでは対傾構とみなされる構造について, その形 式を図一1のように分類した.

図の（1）は，本来床組として設計された横桁（鋼床版 桁では横リブ）とこれを支持する腹板の垂直補剛材を兼 ねた柱部材により，門形ラーメンを形成したものである (例：Inn 橋 $\left.{ }^{4}\right)$. (2) は構造高の大きなトラスを用いた ものである (例: Schierstein 橋 ${ }^{18)}$, 新十三大橋5) ${ }^{5}$ ). (3) は (1)の形式で横桁（ないしは横リブ）の支持部を方杖 によって補剛したものである(例：Golden Horn 橋7), 長柄橋)。（4），(5) はトラス構造の横桁を主体に，(1) のラーメン形式あるいは (3) の方杖形式を組合せて構成 したものである (例：Grenzwald 橋 ${ }^{19}$ ). これらの補剛 構造の中には, 一般のいわゆる対傾構に比較して, 主桁 の断面変形を防ぐ効果が小さいと考えられるものも含ま れる.このため本文では, “対傾構” に代えて, “横断面 補剛部材”とよぶことにする. 鋼床版桁橋では，(2), (4)，(5) のトラスを用いる形式は, 通常数本おきの横り ブ位置に配置される.また，(3) は各横りブ位置に設け られるか,まれに間隔を大きくとった例も見受けられる。

横断面変形に関する力学特性加考えると (2), (4), （5）のトラスを用いる形式は，(1)，(3) の形式におい て, 横桁 (ないしは横リブ) の構造高を大きくし, 剛性 を増加させることと同等であり，この意味において，
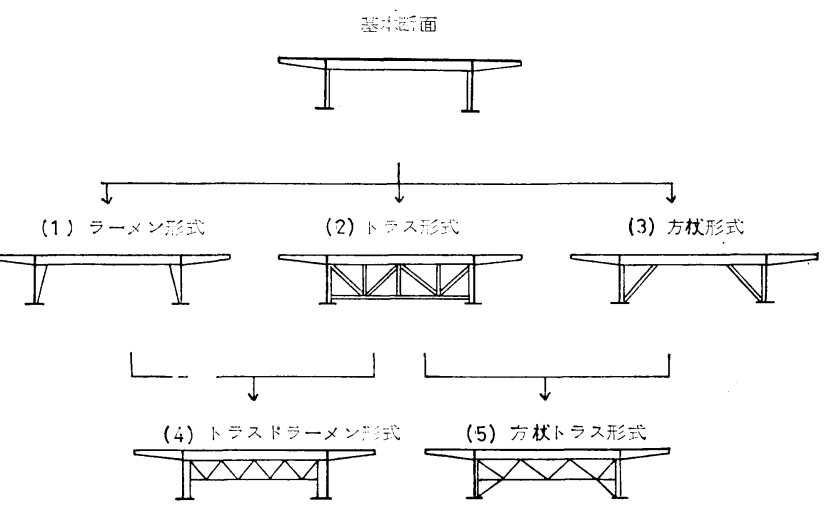

図一1 横断面の補剛形式
(1)，(3) の修正形式とみなすことができる．したがっ て, (1), (3) の 形式に関して, 横断面変形に与える影 響が明らかになれば，その他の形式はこれをもとに推論 することも可能と考えられる.

さて，(1)，(3) の形式のように, 著しく軽量化され た補剛構造が用いられる場合, 横桁 (ないしは横リブ) の変形に伴い,これと結合された主析にも影響を及ぼ し, 主桁下フランジは水平方向に変位を生じる（図一2 (a)).

変位を生じた下フランジは, 支承や他の横断面補剛部 材の拘束を受けているため, 水平方向の曲げモーメント を生じることになる．これによる垂直応力は主桁下フラ ンジの設計において 無視できないものとなることがあ り, また連続析の場合, 中間支点近傍の座屈強度につい ても影響を与えるものと考えられる. 図一2 (b) は最も 基本的なラーメン形式について, 応力度に注目し横断面 変形を考慮した計算結果の一例を従来の計算法による結 果と対比し，モデル化して示したものである.これによ れば上フランジ, 腹板では解法の違いによる応力差は小 さく，下フランジに大きな差異が認められる．そこで主 桁下フランジに関して, 横断面変形による影響を抽出す るため次のような物理量を考える.

水平曲げ応力度 : $\sigma_{H}=\left(\sigma_{C O}-\sigma_{B}\right)$ or $\left(\sigma_{B}-\sigma_{C I}\right)$

水平曲げモーメント : $M_{H}=\sigma_{H} \times W$

付加応力度: $\Delta \sigma=\left|\sigma_{C O}-\sigma_{T B O}\right|$ or $\left|\sigma_{C I}-\sigma_{T B I}\right|$ 付加曲げモーメント : $\Delta M=\Delta \sigma \times W$

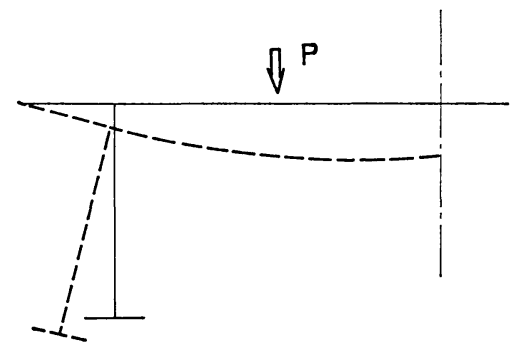

（a）变形状態

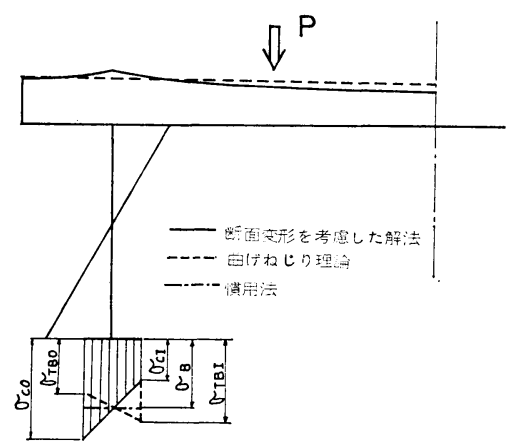

（b）応力分布状態

図一2 横断面変形モデル図 
ただし， $\sigma_{B}$ は慣用法による主桁下フランジの応力度， $\sigma_{T B}$ は曲げねじり理論による応力度, $\sigma_{C}$ は横断面変形 の影響を含めた応力度, $W$ は下フランジの水平方向断 面係数とする. また, 添字 $I, O$ は主桁下フランジの内 側, 外側を示す.

これらの変位や応力は, 従来の設計では無視されてき たものである. したがって，以下の各章では特にこの点 を重視して, 検討を加える. その場合, 横断面の補剛構 造としては, 最も単純化された軽量化追求の基本形と目 されるラーメン形式および方杖形式の二者に着目する.

\section{3. 横断面変形を考虑した 2 主桁橋の構造解析}

本研究においては，2 主标橋の構造解析にあたり，横 断面変形とせん断遅れを考慮したふたつの解法を適用し た. そのひとつは坂井・長井・佐野によるブロック有限 要素法 ${ }^{15)}$ に, 2 主桁橋の解析に適用できるように若干の 修正を加えたものである.いまひとつは，この種の構造 の実用解を得るために，新たに考案した高自由度要素に よる有限要素法である．前者のブロック有限要素法につ いては箱桁を対象として, 文献 15)に詳述されており， ここでは，2 主桁橋の解析に際して考慮したブロックの 変位のみを図一3に示す. 後者の高自由度有限要素法に ついて，その概略を述べると次のようである.

2 主桁橋の解析にあたって, 現在, すでに実用化され ている板・はり・柱に関する一般的な有限要素法を適用 し, 精度のよい解を得ることは, 最近の計算機の容量, 計算能力の向上を考えると, 必ずしも不可能ではない. しかし, 実施設計において, 数径間の連続長大 2 主桁橋 全体を対象にこれを適用することは，費用，その他の点 で適切とはいい難い，そこで，実際の設計において要求 される精度を確保し，かつ，計算時間の短縮をねらいと して, 高自由度要素による有限要素法の開発を試みた。 この解法の特徴は次のようである.

(1) 構造物を比較的大形要素に分割し, 計算時間の短 縮を図る。

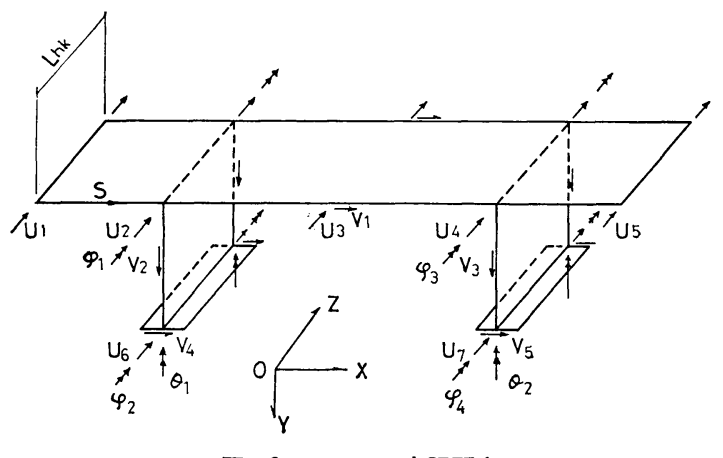

図一3プロック有限要素
(2) 構造物を橋軸直角方向に分割し，各ブロックは板 とそれを補剛する骨組要素によって構成する.

(3) 要素の辺および内部の中点に, 設計上重要と考え られる自由度を補足する。

(4) ブロックの内部に含まれる断面補剛材について は，仮定した変位関数により変位が規制されるもの と考え，その効果を考慮する。

(5) 板に関しては，面内変位のみでなく，面外変位も 考慮する.

(6) 板の面内応力については，せ九断遅れを考慮す る.

(7) 縦リブ等によって補剛された板は直交異方性板と して取り扱う.

次に変位関数については, 数式の単純化と, 要素の中

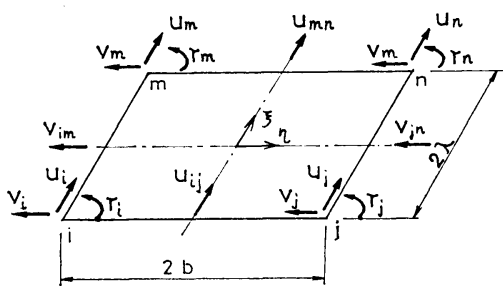

板の画的洛柇

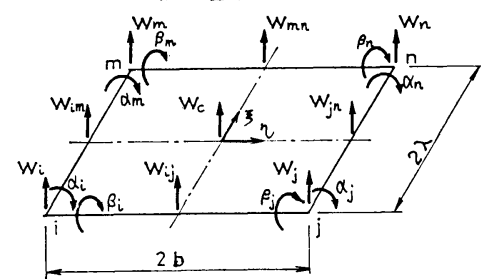

极の面外要形
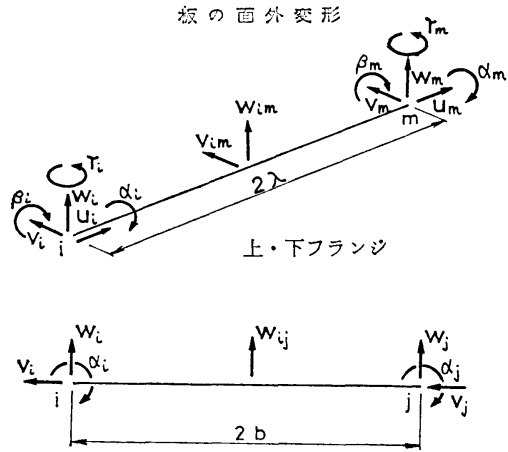

模引フ、领画紼刷村

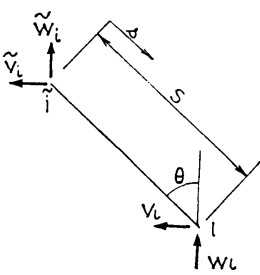

図一4 高自由度要絭 
点に変位自由度を追加していることを考慮し，おもに 4 次関数によって表現した. 図一4に板・はり・柱の高自

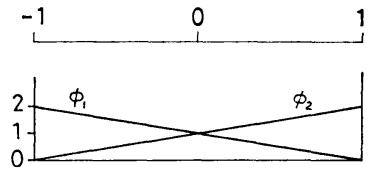

$\phi_{1}(x)=1-x$

$\phi_{2}(x)=1+x$

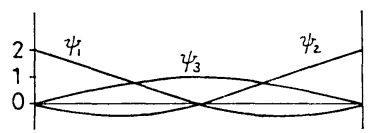

$\psi_{1}(x)=-x+x^{2}$

$\psi_{2}^{\prime}(x)=x+x^{2}$

$\psi_{5}(x)=1-x^{2}$

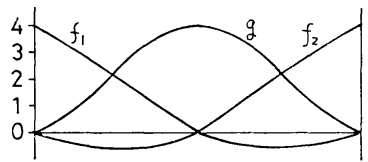

$f_{1}(x)=-3 x+4 x^{2}+x^{3}-2 x^{4}$

$f_{2}(x)=3 x+4 x^{2}-x^{3}-2 x^{4}$

$f_{2}(x)=4-8 x^{2}+4 x^{4}$

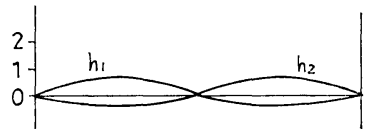

$h_{1}(x)=-x+x^{2}+x^{3}-x^{4}$

$h_{2}(x)=-x-x^{2}+x^{3}+x^{4}$
由度要素とその自由度を, 図一5に変位関数を示す。こ れらの要素を組合せて，ひとつの単位ブロックを形成す ることが可能であり，これを橋軸方向に連続させ，荷重 に応じて必要な応力, 変形が求められる.

\section{4. 数値計算結果と実橋載荷実験結果の比較}

前章の解析法を適用し，鋼床版 2 主析橋の実施例（図 一6）について，できるだけ忠実に実橋をモデル化し， 数值計算を実施した. なおこの場合，横断面補剛部材に 協力するデッキプレート・主桁腹板について，有効幅を 考慮している.この有効幅の大きさは，個々の部材の剛 性に影響するが，作用断面力の種類や分布状況によって 異なり, 厳密には複雑となる.ここでは簡単のため, 道 路橋示方書に準じて算定することにした．また，同橋に 対して行った載荷実験結果との比較も試みた ${ }^{16)}$. 図一7, 8 は載荷荷重 (トラック, 約 $20 \mathrm{t} /$ 台) の配置乞応力度の 計測位置を示したものである。

実験值と解析值の比較の一例として，B荷重を載荷し た場合の 3 断面の橋軸方向応力度を 表一 1 に示す（以下 簡単のために,ブロック有限要素

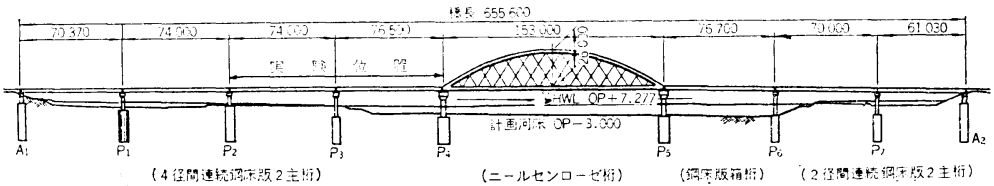

(剆 面 图)

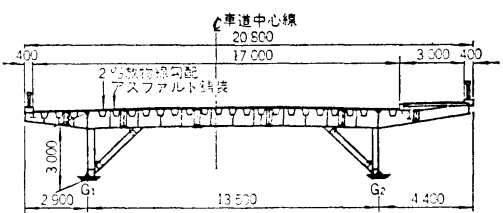

図一6 長柄橋一般図
(標準断面困) 法を $\mathrm{BF}$ 法, 高自由度有限要素法 を $\mathrm{KB}$ 法で表わす). デッキプレ 一トの応力度については, 実験值 と各解析值の間に著しい差異は認 められない. 一方, 主桁下フラン ジの水平曲げ応力度は, 中間支点近傍の (a) 断面で大き く，径間中央の (1) 断面で小さく現われている. その值 は実験值に注目する場合, 慣用法による応力度の 4 25 \% に達している. 図一9 は A 荷重を載荷した場合の下 フランジの水平変位分布を示したものである. 実験值と ふたつの解析値はよく一致しており特に水平変位分布に おいては， $\pi$ 形断面の回転変形と断面変形の関係が明確

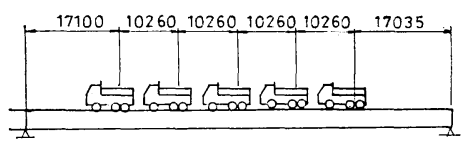

B

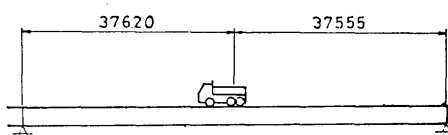

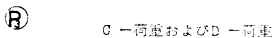

(2)

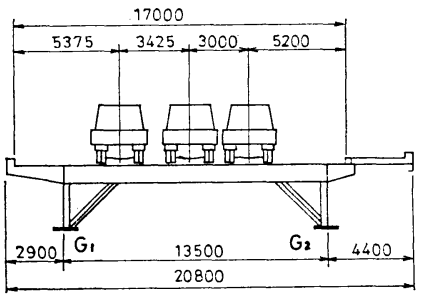

B一荷重 (トラック/5台) ロ一荷连 (トラック台)

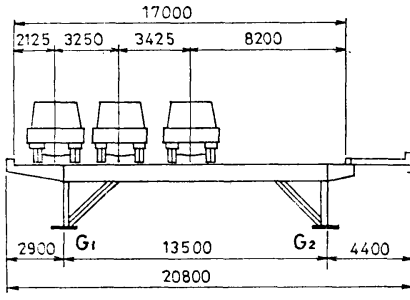

A一荷重(トラック/5台)

C一菏重 (トラックア念)
に現われている，すなわち， $\mathrm{G}_{1}$ 桁については, $\pi$ 形断面の回転変 形汇対して断面変形がそれを打ち 消す方向に， $G_{2}$ 桁については, 増大寸る方向に作用するため, $\mathrm{G}_{2}$ 桁の水平変位が $G_{1}$ 桁のそれより 大きな值を示している。

次に，D荷重を径間中央に載荷 した場合の下フランジの水平曲け゚ モーメント分布を図一10 に示す. ふたつの解析値の分布性状は, 弾 性支承上のはりに集中荷重を載荷 した場合の曲げニーメント分布と 類似している.このことは，下フ 

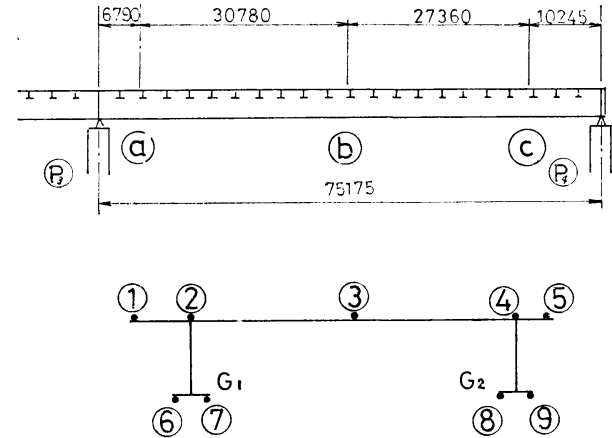

図一8 計 測 位 置

表一1 B 荷重による橋軸方向応力

(単位 $: \mathrm{kg} / \mathrm{cm}^{2}$ )

\begin{tabular}{|c|c|c|c|c|c|c|}
\hline Sect & in & 慣用法 & \begin{tabular}{|l|} 
㤟:゙ねじり \\
理 論 \\
\end{tabular} & B.F. 法 & K.B. 法 & Exp. \\
\hline & (1) & - & 64 & 73 & 71 & 69 \\
\hline & (2) & 86 & 60 & 73 & 88 & 84 \\
\hline & (3) & - & 51 & 54 & 53 & 49 \\
\hline & (4) & 77 & 42 & 68 & 86 & 64 \\
\hline (a) & (5) & - & 40 & 63 & 85 & 54 \\
\hline & (6) & -130 & -110 & -191 & -191 & -144 \\
\hline & (7) & -130 & -113 & -89 & -94 & -77 \\
\hline & (8) & -96 & -88 & -33 & -48 & -65 \\
\hline & (9) & -96 & -91 & -162 & -140 & -125 \\
\hline & (1) & - & -327 & -301 & -282 & -253 \\
\hline & (2) & -345 & -311 & -285 & -299 & -283 \\
\hline & (3) & - & -273 & -263 & -246 & -287 \\
\hline & (4) & -304 & -234 & -277 & -296 & -249 \\
\hline (b) & (5) & - & -226 & -296 & -292 & -242 \\
\hline & (6) & 619 & 582 & 644 & 660 & 585 \\
\hline & (7) & 619 & 597 & 566 & 530 & 538 \\
\hline & (8) & 446 & 487 & 417 & 404 & 409 \\
\hline & (9) & 446 & 504 & 472 & 506 & 448 \\
\hline & (1) & - & -156 & -140 & -143 & -108 \\
\hline & (2) & -158 & -148 & -137 & -142 & -120 \\
\hline & (3) & - & -130 & -129 & -115 & -109 \\
\hline & (4) & -150 & -111 & -146 & -142 & -109 \\
\hline (C) & (5) & - & -107 & -142 & -135 & -100 \\
\hline & (6) & 366 & 328 & 287 & 282 & 274 \\
\hline & (7) & 366 & 337 & 478 & 422 & 371 \\
\hline & (8) & 231 & 276 & 311 & 268 & 240 \\
\hline & (9) & 231 & 285 & 169 & 186 & 190 \\
\hline
\end{tabular}

ランジの水平方向の挙動を近似的にモデル化する場合, 方杖材を弾性ばねとした弾性支承上のはりとして取り扱 らことの妥当性を裏ゔけるのといえる. しかし数值的 には, 実験值 $<\mathrm{KB}$ 法 $<\mathrm{BF}$ 法となっている. 特にひ とつの集中荷重を載荷した場合に，その差が顕著に現わ れている.このことは次のような理由によるものと思わ れる. 実験值がふたつの解析值より小さいのは, 実橋に おいては, 添加物を支持する部材が横リブの補剛材とし て作用し, 横断面の剛性が解析データよりも大きくなっ ていることによるものと考えられる．また，ふたつの 解析值の差異は, BF 法においては, デッキプレートの 面外剛性を無視しているため, デッキプレート上に載荷
された荷重は，橋軸方向に分配されず，載荷点直下の方 杖材により下フランジに直接伝達され，下フランジに対 してひとつの集中荷重として作用すると考えられる。一 方，KB 法に打いては，デッキプレート上に載荷された 荷重は，縦リブを含むデッキプレートの面外剛性によっ て分配され，荷重載荷点から，ある範囲の方杖材によっ て下フランジに作用すると考えられる.この点がふたつ の解析値の差として現われていると考察される.

以上の実橋を対象とした数值計算，および実測值に対 する考察から, 次の点が指摘される。

(1) 主桁上フランジとしてのデッキプレートおよび腹 板の設計においては，横断面変形の影響は小さく， 実際設計ではこれを無視してもよいと考えられる.

(2) 断面変形の影響は主桁下フランジ，特に連続桁の 中間支点および端支点近傍で大きく, 主桁下フラン ジの設計において，十分に検討する必要がある.そ の場合, 主桁下フランジの水平方向の挙動は, 弾性 支承上のはりに類似している。

\section{5. 横断面補剛部材が主桁下フランジに及ぼす 影響}

横断面の変形に起因する主桁下フランジの水平変位, 付加応力度が, 横断面の補剛形式, 部材の配置, 形状寸 法, あるいは荷重位置や着目点により, どのように変化 するかは興味深い問題であり，また，これらの設計因子 との関係を定性的ないしは定量的に明らかにすること は，設計上重要であると考えられる．そこで，このよう な観点から鋼床版 2 主析橋について, 基本的な等断面単 純支持桁を対象とし，主要な設計因子をパラメーターに 選び解析を試みた。鋼床版 2 主桁橋においては，2。で 述べたようにラーメン形式や方杖形式のほかに，トラス を用いた形式のものも採用されている.しかし，これら の形式ではその構造が横断面の変形に及ぼす効果を考え る場合, ラーメン形式の横リブ腹板高を大きくし，曲げ 剛性を増加させることと同等とみなすことができる．し たがって，補剛形式としては，ここではラーメン形式と 方杖形式の 2 者に着目する. また, 設計上のパラメータ 一として, 次の諸量に注目し, これらは付記の範囲内で 変化するものとする

(1) 支 間: $L=72 \sim 120 \mathrm{~m}$

(2) 主桁間隔: $B_{G}=10 \sim 20 \mathrm{~m}$

(3) 腹 板 高: $H_{W}=3.84 \sim 6.00 \mathrm{~m}$

(4) 下フランジ断面（幅，厚さ) :

$$
\begin{aligned}
& B_{f}=120 \sim 150 \mathrm{~cm} \\
& t_{f}=4 \sim 8 \mathrm{~cm}
\end{aligned}
$$

(5) 横リブ剛度（横リブ腹板高）： 


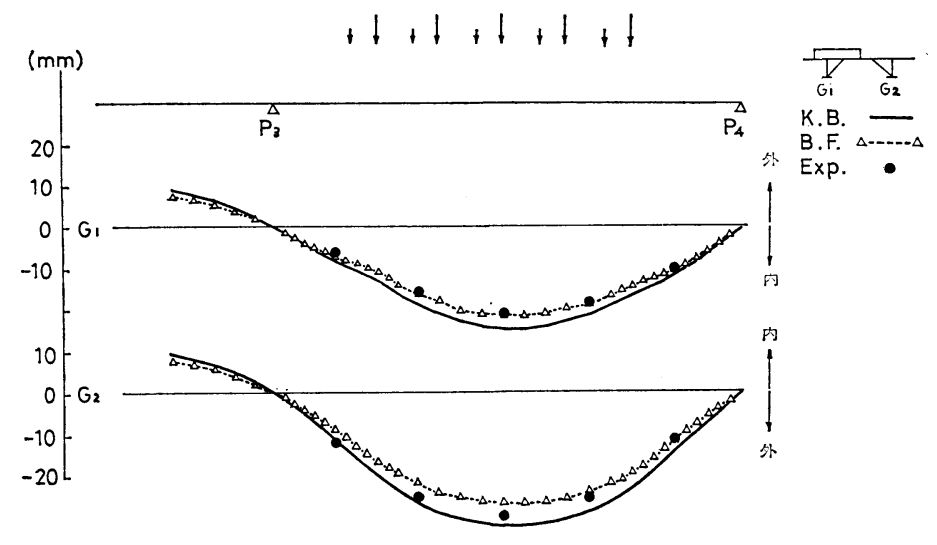

図一9Ａ荷重による下フランジの水平変位

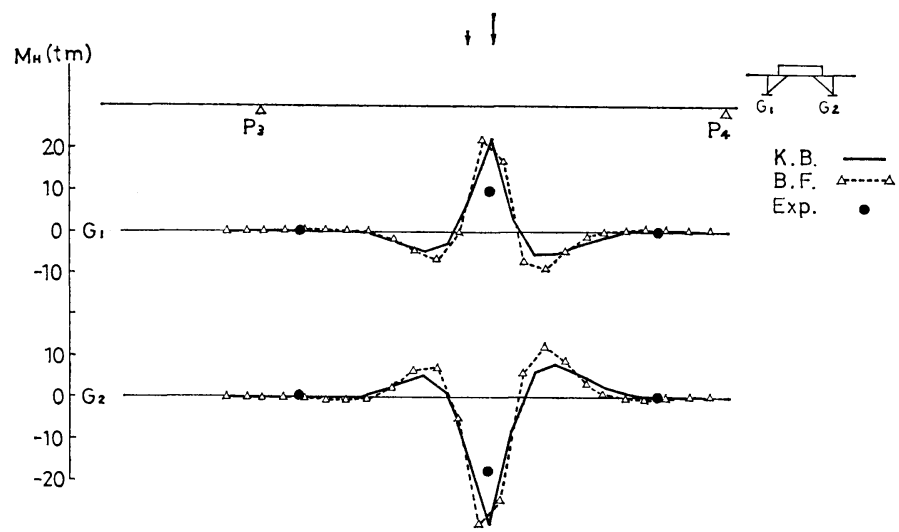

図一10Ｄ荷重による下フランジの水平曲げモーメント
橋示方書の TL-20 荷重により設計を 行い, 支点上には, 実際に即して剛性 の大きな横桁を配置した. また, 数值 計算はブロック有限要素法を 適用し た. 以下に数值計算結果を整理し, そ の概要を述べる.

\section{（1）載荷荷重の違いによる付加応 力分布の差異}

図一12 は, 集中荷重 $P(=1 \mathrm{t})$ と分 布荷重 $q(=1 \mathrm{t} / \mathrm{m})$ を載荷した場合に 対し, 水平付加曲げモーメントに注目 して図示したものである.この計算結 果より, 次の事項が考察される.

(1) 付加曲げモーメントの分布性状 は荷重の種類により著しく異な る.

(2) 集中荷重による影響は局所的で ある。

(3) 前章の方杖形式をもつ構造と同 じょうに, ラーメン形式において も, 下フランジの水平方向の挙動 は, 横断面補剛部材を弾性支承と したはりと類似している.

\section{（2）支間長の影響}

横断面の中央に単位集中荷重を載荷

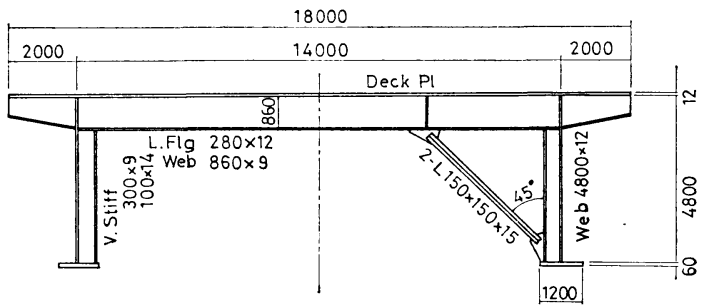

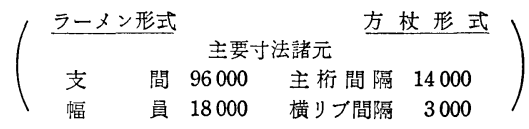

$$
\begin{aligned}
& \text { 図一11 パラメーター解析の基本構造 }
\end{aligned}
$$

$$
H_{C}=70 \sim 110 \mathrm{~cm}
$$

(6) 横リブ間隔: $\lambda=1.5 \sim 6.0 \mathrm{~m}$

このうち, パラメーター解析の基本構造としては, 実 施例を参照し，次の諸元を採用する（図一11）.

$$
\begin{array}{lrr}
\text { 支 } & \text { 間 } & L=96 \mathrm{~m} \\
\text { 幅 } & \text { 員 } & B=18 \mathrm{~m} \\
\text { 主桁間 隔 } & B_{G}=14 \mathrm{~m} \\
\text { 横リブ間隔 } & \lambda=3 \mathrm{~m}
\end{array}
$$

なお, 鋼床版, 下フランジ, その他の構成要素は道路
した場合の付加曲げモーメントは 図一12 のようになる が，載荷位置を橋軸方向に順次移動させると，それぞれ の載荷位置に生じる最大付加曲げモーメントを結ぶ包絡 線が得られる. 図一13 は支間長の大小により，この包 絡線がどのように変化するかを示したものである. 図か ら明らかなように付加曲げモーメントの最大值は, 支点 近傍で急激に増大し，ここでの計算ではすべて支点から 3 パネル離れた補剛部材位置 ( $3 \lambda=9 \mathrm{~m}$ の位置) で最大 となる. その後はやや減少し, 径間中央部ではほぼ一定 值となっている. すなわち横断面が同一であれば, 最大 付加曲げモーメントの大きさ, 分布性状は, 支間長にほ とんど影響を受けず，支間長の変化量のみ径間中央部の 一定值の範囲が変化するだけとなっている．等分布荷重 を満載する場合の付加曲げモーメントについても, ほぼ 同様のことがいえる.

\section{（3）主析間隔および腹板高の影響}

前述のように, 図一13 より, 付加曲げモーメントの 分布性状は, 支間中央部の一定の曲げモーメントと桁端 近傍の最大曲げモーメントに代表される．したがってこ 

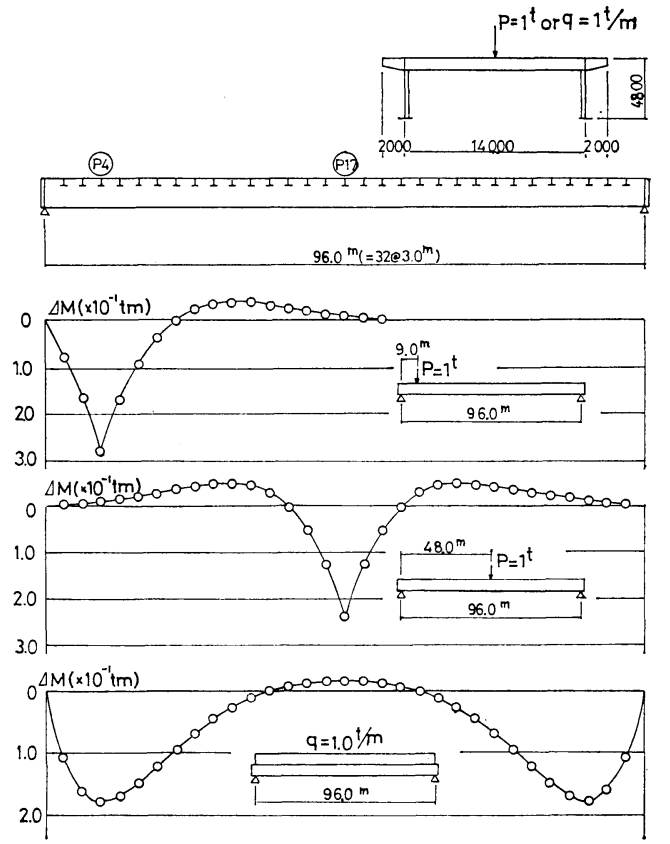

図一12 集中荷重等および分布荷重による付加曲げ モーメント

こでの整理は, 荷重載荷点を次の 2 点に限定して行うこ ととした.

(1) 格点 4 (端支点から 3 パネル離れた位置): 最大 付加曲げモーメント発生点

(2) 格点 17 (支間中央)：等曲げ領域の中央

図一14 は横軸に主桁間隔, 縦軸に付加曲げモーメン トをとり，腹板高をパラメーターとして整理したもので ある.これによれば，主桁間隔が大きくなるほど，ま た, 腹板高が小さくなるほど, 付加曲げモーメントは増 大の傾向を示している. その場合, 主桁間隔の増大に伴 い付加曲げモーメントも大きくなる点については, 横り ブの曲げ変形が大きくなることによるものであり当然と

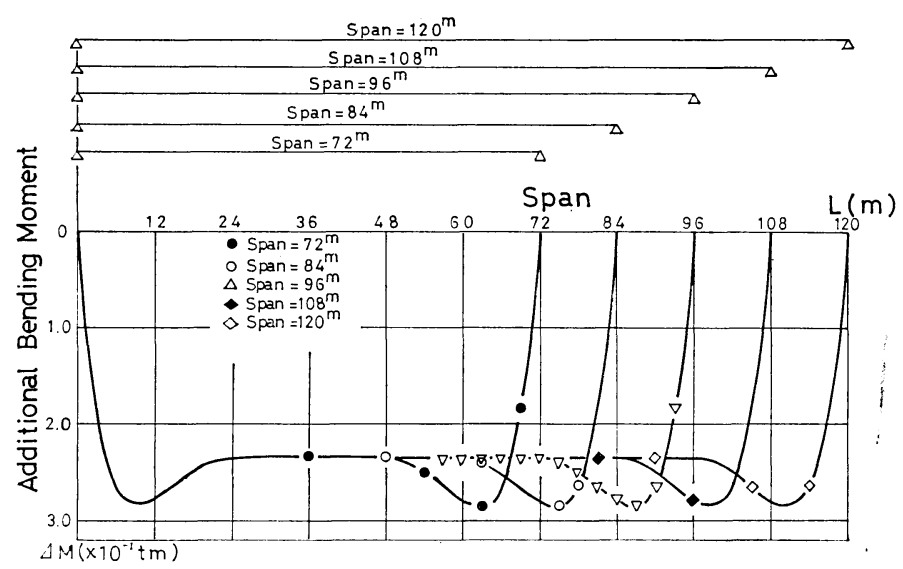

图一13 支間長の変化と付加曲げモーメント

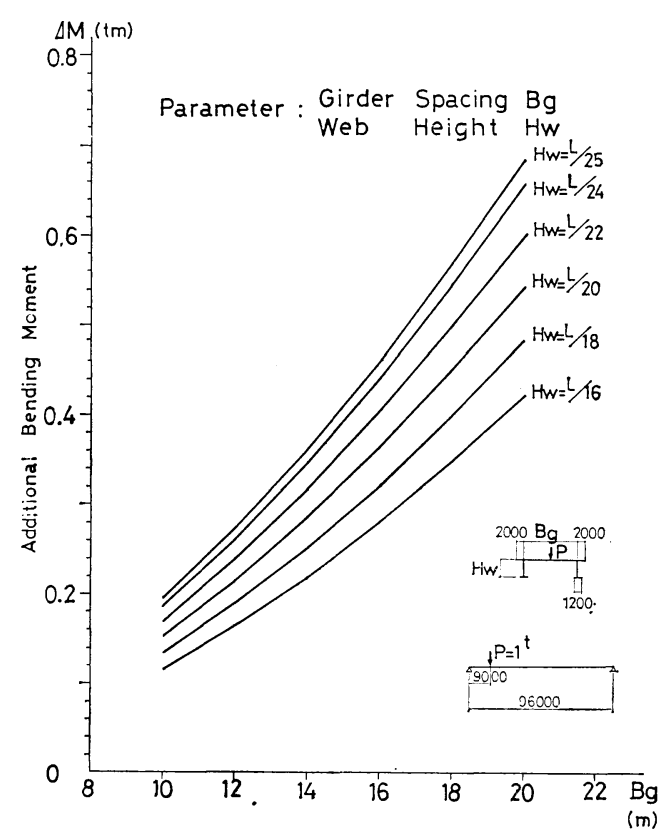

图一14 腹板高, 主析間隔の変化と付加曲げモーメント

いえる. 一方, 桁高の変化に関しては, 腹板高が小さく なると, 主桁の回転変形に対する拘束が相対的に大きく 作用するため, 付加曲げモーメントが大きくなるものと 考えられる。

\section{（4）下フランジの水平曲げ剛性の影響}

下フランジ断面の形状寸法の変化と付加曲げモーメン トの関倸を知るため, 下フランジ幅を一定とし, 板厚を 変化させる場合および断面積を一定とし，下フランジ 幅, 板厚を変化させる場合についても計算を実施した. しかし，ここでの検討では，このパラメーターの変化に よる影響はほとんど認められなかった。

\section{（5）横リブの影響}

鋼床版の横リブは, ラーメン形式や方杖 形式の補剛構造の場合, その主要な構成要 素となっている. そこで, 横リブの曲げ剛 性, およびその間隔と付加曲げモーメント の関連性について検討を加えた。 その場 合, 横リブの曲げ剛性に関するパラメータ ーとして横リブ腹板高 $H_{C}$ を用いている. 図一15 の実線は基本構造について, 横り ブ腹板高の変化と付加曲げモーメントとの 関係を示したものである。また破線は横り ブを主桁上で支持した単純支持ばりとみな し, 過去の実施例より適切な值を選定し, 横リブ腹板高と主桁間隔を同時に変化させ 


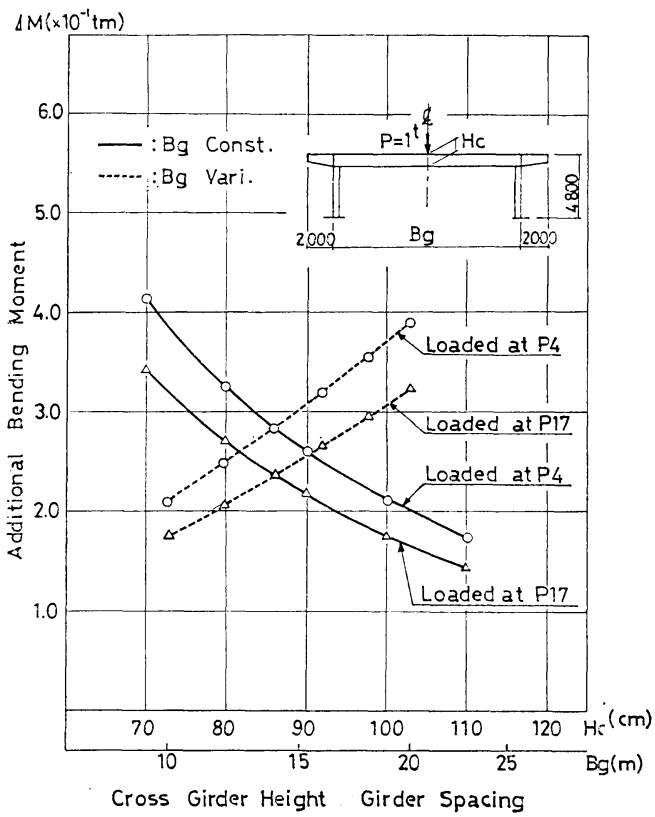

図一15 横リブ剛度の変化と付加曲げモーメント

た場合に対する值を示したものである．前者について は, 付加曲げモーメントは, 横りブ腹板高の増大ととを に急激に減少することが認められる. 一方, 後 者の場合，主桁間隔の影響がより支配的である といえる.

なお，横りブ間隔 $\lambda$ を変化させる場合につ いても計算を実施したが，これによればスの 増加とともに付加曲げモーメントもわずかに増 加するが，その影響は比較的小さいという結果 が得られている.

\section{（6）腹板垂直補剛材の剛性の影響}

図一16 は垂直補剛材の突出幅の変化と付加 曲げモーメントの関係を示したものである.こ れによれば，突出幅の増加とともに，付加曲げ モーメントも増加の傾向を示す.これは 前述の腹板高を小さくする場合と類似し た現象であり，下フランジの水平方向へ の拘束が大きくなるためと考えられる. したがって，付加曲げモーメントに関す る限りでは，垂直補剛材の剛性を必要以 上に大きくするのは，得策でないといえ る.

\section{（7）方杖形式の特性}

実際の広幅員の鋼床版 2 主桁橋では, 横断面の補剛と下フランジの変形防止の 観点から，横リブやトラス横桁に方杖を
併用する例が見受けられる，そこで，方杖の効果を明ら かにするために，ラーメン形式の場合と同様にパラメー ター解析を実施し，両者の比較を試みた。ここでは，そ

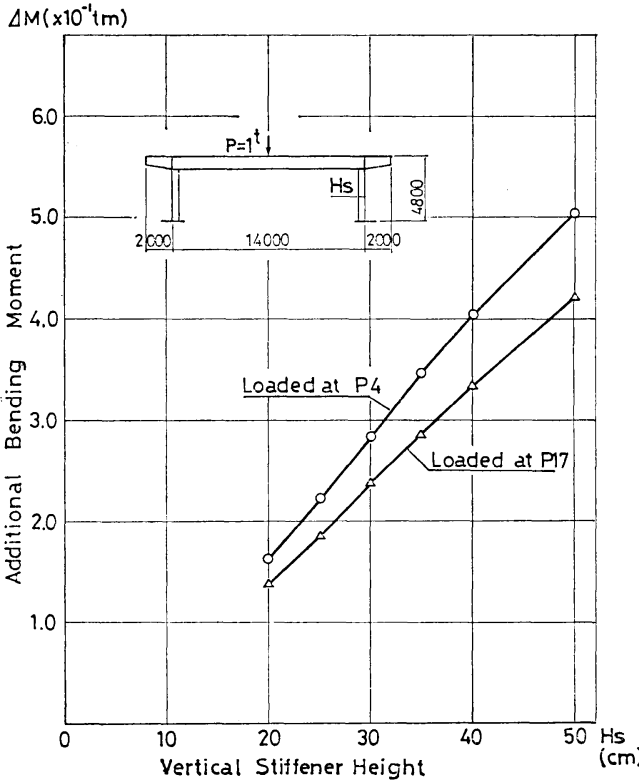

図一16 腹板垂直補剛材剛度の変化と付加曲げモーメント

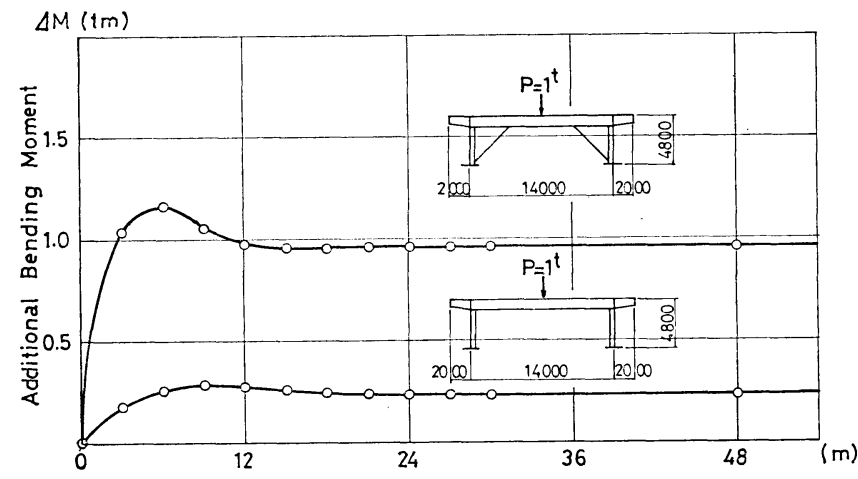

図一17付加曲げモーメントの補剛形式による比較

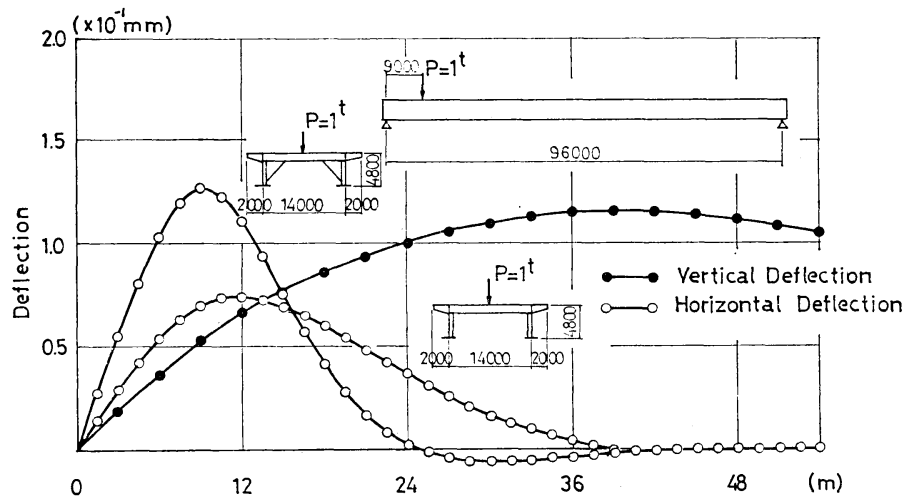

図一18 下フランジ変位の補剛形式による比較 
の計算結果の一例として, 図一17

表一2 下フランジ最大応力度の解析法による比較

(単位 $: \mathrm{kg} / \mathrm{cm}^{2}$ )

に最大付加曲げモーメントの包絡

線を, 図一18に鉛直および水平

変位を示す．図一18 では 鉛直変 位に関して, ラーメン形式と方杖 形式の間で值に差異が認められな いので, 1 本の線で示した. また， 水平変位については，方杖形式の 場合, 支点近傍で急激に大きくな っている. 付加曲げモーメントに 関しては，両者の分布性状は類似 しているが，その值は方杖形式の 方がかなり大きな值を示してい る. 前述の構造諸元に対してパラ

\begin{tabular}{|c|c|c|c|c|c|c|c|c|}
\hline 着目格点 & 横 断面 & 荷重状態 & 慣用法 & $\begin{array}{l}\text { 曲げねじ } \\
\text { り)理 論 }\end{array}$ & B.F. 法 & \multicolumn{3}{|c|}{ 比 } \\
\hline (図-12) & 補剛形式 & $($ 図-19) & $\tilde{\sigma}_{b}$ & $\sigma_{b}+\sigma_{w}$ & $\sigma_{b}+\sigma_{w}+\Delta \sigma$ & $\frac{\sigma_{b}+\sigma_{w}}{\tilde{\sigma}_{b}}$ & $\frac{\sigma_{b}+\sigma_{w}+\Delta \sigma}{\tilde{\sigma}_{b}}$ & $\frac{\sigma_{b}+\sigma_{w}+\Delta \sigma}{\sigma_{b}+\sigma_{w}}$ \\
\hline \multirow{6}{*}{4} & \multirow{3}{*}{$\begin{array}{l}\text { ラーメン } \\
\text { 形 式 }\end{array}$} & 1 & 693 & 712 & 790 & 1.03 & 1.04 & 1.11 \\
\hline & & 2 & 661 & 694 & 722 & 1.05 & 1.09 & 1.04 \\
\hline & & 3 & 676 & 690 & 805 & 1.02 & 1.19 & 1.17 \\
\hline & \multirow{3}{*}{ 方杖形式 } & 1 & 693 & 712 & 979 & 1.03 & 1.41 & 1.38 \\
\hline & & 2 & 661 & 694 & 855 & 1.05 & 1.29 & 1.23 \\
\hline & & 3 & 639 & 651 & 1048 & 1.02 & 1.64 & 1.61 \\
\hline \multirow{6}{*}{17} & \multirow{3}{*}{$\begin{array}{l}\text { ラーメン } \\
\text { 形 }\end{array}$} & 1 & 2046 & 2112 & 2076 & 1.03 & 1.01 & 0.98 \\
\hline & & 2 & 1944 & 2046 & 2017 & 1.05 & 1.05 & 0.99 \\
\hline & & 3 & 1996 & 2038 & 2006 & 1.02 & 1.01 & 0.98 \\
\hline & \multirow{3}{*}{ 方杖形式 } & 1 & 2046 & 2112 & 2171 & 1.03 & 1.06 & 1.03 \\
\hline & & 2 & 1944 & 2046 & 1976 & 1.05 & 1.02 & 0.97 \\
\hline & & 3 & 1939 & 1969 & 2173 & 1.02 & 1.12 & 1.10 \\
\hline
\end{tabular}

$\tilde{\sigma}_{b}: 1-0$ 分配影響線から計算した曲け応力度

メーター解析を実施したが，傾向はラーメン形式と同様 であり，その值のみがラーメン形式に比較してかなり大 きく現われている.これは, 方杖材, 横リブ, および腹 板の垂直補剛材により，三角形の剛な構面が形成され， 横リブの変形が腹板の変形によって緩和されることな く, 直接下フランジへ伝達されるためと考えられる.す なわち, ラーメン形式に扮いて垂直補剛材の剛性を極端 に大きくした場合と同様の現象といえる.したがって， 下フランジの付加曲げモーメントおよび水平変位に関す る限りは，方杖材を設けることによる断面変形を抑制す る効果は少ないと考えられる.

\section{（8）設計実荷重に対する検討}

道路橋示方書に規定される TL-20 荷重を載荷する場

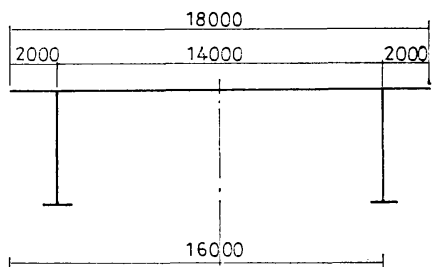

Load Case

$\left(\sigma_{b}\right.$ 最大時)

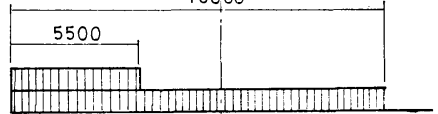

Load Case 2

( $\sigma_{\omega}$ 最大待)

9000

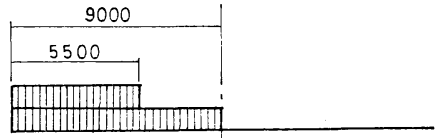

※转荷筙囲は

Load Case 3

$\left(\sigma_{b}+\tau_{\omega}+\Delta \sigma\right.$ 最大洔

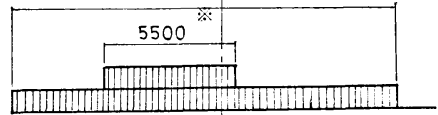

図一19載荷設計荷意
合について, 従来の慣用法, 曲げねじり理論, およびブ ロック有限要素法の 3 種の解法により, 主桁下フランジ の最大応力度にどの程度の差異が生じるかを検討した.

ここでも，図一11 の基本構造を対象とした．図一19に 荷重配置を示す。また, 荷重は死荷重を $450 \mathrm{~kg} / \mathrm{m}^{2}$ と 仮定し, 活荷重の横断方向の載荷は, 実際の設計や各解 析法の特徴を考慮して, 次の 3 ケースとした.

Case-1 : 曲げ応力度 $\left(\sigma_{b}\right)$ 最大時

Case- 2 : そり応力度 $\left(\sigma_{w}\right)$ 最大時

Case-3 : 合計応力度 $\left(\sigma_{b}+\sigma_{w}+\Delta \sigma\right)$ 最大時

なお, Case-3 の荷重状態は影響線を描いて載荷位置 を決定した. 表一2 に計算結果の比較を示す.これよ り，慣用法と曲げねじり理論による計算值の比は下フラ ンジに対して 1.02 1.05 程度で, 大きな差異は認めら れない，しかし，慣用法と BF 法による值を比較する と，いずれも $\mathrm{BF}$ 法の方が大きくなっており，特に方 杖形式の格点 4 においては 1.64 倍もの值を示してい る. また，曲げねじり理論と BF 法の結果をCase-3 について比較すると, ラーメン形式では格点 17 におい て，後者が前者より大きくなっている，一方，方杖形式 では格点 17 で 10\%，格点 4 で 60\% 程度, BF 法の 方が大きくなっている．ただし本計算例では等断面桁を 仮定して計算を行っており，断面変化を考慮する場合に は，上記の結果は若干変化するものと考えられる．この ように，横断面変形を無視する解法では，特に支点近傍 の主桁下フランジにおいて危険側の設計となることは明 らかである.しかし，実際設計の場合，このような付加 応力に対しては，支点近傍の一部の断面を補強すること によって，比較的容易に対処することが可能である.

\section{6. 簡易モデルによる近似解法}

前述のように 2 主桁橋では横断面変形の影響により, 
(1)

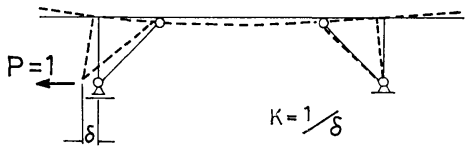

(2)

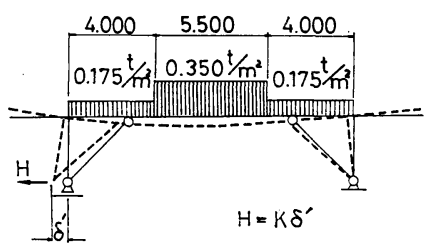

(3)

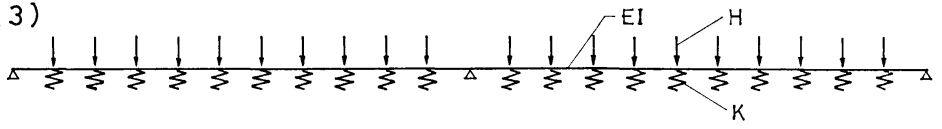

图一20 简易モデル

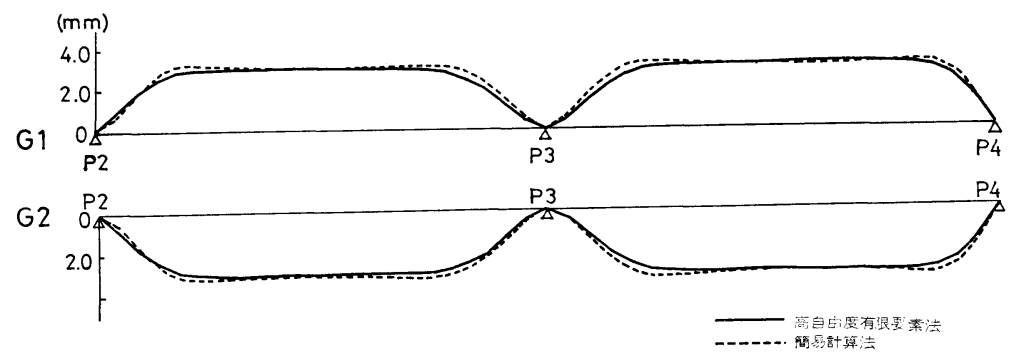

图一21近似解法による下フランジの水平変位

載荷状態が異なる場合や, 付加曲 げモーメントに関する比較でも， 同様に良好な結果が得られてい る.これらを総合して 2 主桁橋の 横断面変形が主桁下フランジに与 える影響は, 弾性支承上のはりと して, 近似的に表現することが可 能と考えられる。

\section{7. まと め}

本研究では, 横断面補剛部材が 著しく軽量化された鋼床版 2 主桁 橋について, 横断面変形を考慮し た $2 つ の$ 解析法を適用し, 実験結 果との対比を行うとともに, 補剛 部材の形式や構成要素が変化する 場合に対して, 考察を加えた. そ れらの結果を整理すると以下のよ うである。

主桁下フランジにおいて, 水平方向に相当の大きさの変 形とそれに伴う応力が発生し, その挙動は弾性支承上の はりに類似していることが判明した. この現象に対し て, 実際設計の立場からは, 常に複雑な解析を実施する のは適切とはいい難く, 可能であればより簡単なモデル を設定し，妥当な設計值を得ることが望ましいと考えら れる. そこで, 主桁下フランジのみを取り出し, 弾性支 承上のはりとしてモデル化することを試みた. モデル化 の手順は次のようである(図一20).

(1) 弾性支承のばね定数は，デッキプレートや腹板の 有効幅を考慮した横桁 (ないしは横りブ), および垂 直補剛材, ならびに方杖材で構成される横断面方向 の骨組の下フランジ位置に, 単位荷重 $P=1$ を加え たときの変位量 $\delta$ から求める (図一20 (1)).

$$
K=1 / \delta
$$

(2) 水平力は, 上記の骨組に所定の荷重を載荷し, そ のときの下フランジ位置の水平変位量 $\delta^{\prime}$ を計算し, これにば社定数 $K$ を掛けて求める（図一20 (2)).

$$
H=K o^{\prime}
$$

(3) 下フランジの水平曲げ剛度 $E I$ を弾性支承上のは 门の曲げ剛度とする.

このように設定したモデルに対し，図一6 の 2 主桁橋 を対象に道路橋示方書による等分布活荷重を 図一20 (2) のように載荷し計算を行った. この結果と, 高自由度有 限要素法を適用し, 同一荷重に対して解析した結果を変 位について比較すると 図一21 のようである. 両者の值 はよく一致している.ここでは比較の一例を示したが,
(1) 鋼床版 2 主桁橋の横断面補剛形式を軽量化し, 簡 易な構造とした場合，主桁下フランジの設計におい ては横断面変形の影響は無視できない。

(2) 横断面変形の影響は, 端支点近傍，および連続桁 の中間支点近傍で大きく, 径間中央では比較的小さ い.

(3) 横断面変形の影響は主桁下フランジの水平方向一 の挙動として現われ，その場合，主桁下フランジは 補剛材位置を弾性支承とした連続ばりと類似した力 学特性を示す.

(4) 横断面の変形によって, 主桁下フランジに発生す る付加曲げモーメントは, 荷重の種別により, その 分布性状は著しく異なるが, 集中荷重に対しては局 所的である.

(5) 主桁下フランジの付加曲げモーメントを支配する 構造諸元は, 主桁間隔・腹板高・横リブおよび垂直 補剛材の曲淍性等であり, 支間長, 下フランジの 水平曲げ剛性の影響は比較的小さい.

(6) 方杖形式とラーメン形式の比較では, 主桁下フラ ンジの変位および付加曲げモーメントに関する限り は，後者の方が有利となる結果が得られた。

(7) 実際の設計において，横断面変形を考慮せずに， 主桁下フランジを設計する場合, 特に支点近傍にお いて危険側の設計になると考えられる．ただし，下 フランジ断面を補強することにより，比較的容易に 対処することができる.

以上のような結果から，ラーメン形式や方杖のような 
簡易な補剛形式を用いる場合，設計上特に次の点に留意 する必要があると考えられる，ひとつは横断面変形に 伴って, 支点近傍の主桁下フランジに発生する, 比較的 大きな 付加応力に 関する応力問題である. いまひとつ は，圧縮領域となる連続桁中間支点近傍の下フランジの 安定問題である．前者については，本文で述べたような 計算法によって照査することが可能であり，下フランジ 断面の比較的わずかな修正で容易に対処することができ る.また後者については本文では言及していないが，圧 縮下フランジの座屈に関する検討の一例を，別途文献 17）で取り扱っており，特に設計が困難になるような結 果は得られていない。このように，鋼床版 2 主桁橋の構 造計画に際しこれらの形式が有効に利用できるものと 考えられる. その場合, 軽量化の点では, ラーメン形式 がより効果的といえよう。このほか，設計では横荷重が 作用する場合や断面内の温度差がある場合の横断面変形 の影響についても照査する必要があるが，これらに関し ても同様に，6. の近似解法の適用が可能であると考え ている.

おわりに，本研究の実施に際して，懇切なご指導と貴 重なご助言を賜った京都大学 小西一郎名誉教授, 名古 屋大学 福本唀士教授に深く感謝いたします．また，現 場実験，数值計算等の実施にご協力いただいた川崎重工 業 (株)，日本橋梁（株），日本電子計算（株）に，紙上 を借りお礼を申し上げます。

\section{参 考 文 献}

1）小西一郎編：鋼橋，設計編 I, pp. 508 512, 丸善, 1975.

2) Guyer, R. : Die st. Alban-Brücke über den Rhein in Basel. II. Der Stahlüberbau, Schweizerische Bauzeitung, 20, 7, 1957.
3) Homberg, H. : Die neue Sulzbachtalbrücke der Autobahn, Der Stahlbau, 23, 9, 1954.

4) Wagner, P. : Die Innbrücke Kiefersfelden, Der Stahlbau, 38, 9 10, 1969.

5）近藤・井上・加藤・佐々木 : 新十三大橋の工事，橋梁と 基礎, 7 8 号, 1967；1 4 号, 1968.

6）小松定夫 : 薄肉構造物の理論と計算 I, 山海堂, 1969 .

7) Golden Horn 橋 (Turkey) の応力測定, p. 282, 石川島 播磨技報，15，2，1975。

8）Vlasov 著 (奥村敏恵ほか訳)：薄肉弾性梁の理論，技報 堂, 1967.

9) Lacher, G. : Zur Berechnung des Einflusses der Querschnittsverformung auf die Spannungsverteilung bei durch elastische oder Starre Querschotte versteiften Tragwerken mit prismatischem, offenem order geschlossenem biegesteifem Querschnitt unter Querlast, Der Stahlbau, 31, 10, 1962.

10）奥村・坂井 : 箱型壮りの断面変形と中間ダイアフラムの 影響, 土木学会論文報告集，第 190 号，6，1971.

11）奥村・坂井：リブ付台形桁の断面変形挙動とダイアフラ 厶の効果, 土木学会論文報告集，第190 号, 1971.6.

12）落合・北原：箱げたに抢ける隔壁の性状, 橋梁と基礎, $4 \sim 5$ 号, 1970.

13）坂井・長井 : 鋼箱げた橋におけるダイアフラム間隔の決 定に関する一試案, 川崎重工社内報, 5, 1975 .

14）加藤ほか 5 名： 2 主桁橋の設計に関する $2 \cdot 3$ の問題, 土木学会関西支部年次講演会概要集 I - 58, 6, 1978.

15）坂井・長井・佐野：ブロック有限要素法による薄肉箱桁 の立体解析，土木学会論文報告集，第 255 号， 1976.11 .

16）丸山・加藤・八部：三主桁橋の載荷実験について，土木 学会第 34 回年次学術講演会講演概要集 I - 131, 1979. 10.

17）加藤・ 丸山・尾下: 鋼床版 2 主桁橋の下フランジの座屈 性状について, 第 35 回年次学術講演会講演概要集 I131, 1980.9.

18) Weitz, F.R. : Entwicklungstendenzen des Stahlbrückenbaus am Beispiel der Rheinbrücke WiesbadenSchierstein, Stahlbau, 35, 10, 1966.

19) Hofmann, R.: Die Grenzwaldbrücke und die Sinnbrücke der Rhönautobahn, Stahlbau, 8, 1969.

(1979.12.31 • 受付) 